\title{
Origins of human genetics. A personal perspective
}

\author{
Eberhard Passarge $\mathbb{D}^{1}$
}

Received: 13 December 2019 / Revised: 28 September 2020 / Accepted: 17 November 2020 / Published online: 4 February 2021

(c) The Author(s) 2020. This article is published with open access

\begin{abstract}
Genetics evolved as a field of science after 1900 with new theories being derived from experiments obtained in fruit flies, bacteria, and viruses. This personal account suggests that the origins of human genetics can best be traced to the years 1949 to 1959. Several genetic scientific advances in genetics in 1949 yielded results directly relating to humans for the first time, except for a few earlier observations. In 1949 the first textbook of human genetics was published, the American Journal of Human Genetics was founded, and in the previous year the American Society of Human Genetics. In 1940 in Britain a textbook entitled Introduction to Medical Genetics served as a foundation for introducing genetic aspects into medicine. The introduction of new methods for analyzing chromosomes and new biochemical assays using cultured cells in 1959 and subsequent years revealed that many human diseases, including cancer, have genetic causes. It became possible to arrive at a precise cause-related genetic diagnosis. As a result the risk of occurrence or re-occurrence of a disease within a family could be assessed correctly. Genetic counseling as a new concept became a basis for improved patient care. Taken together the advances in medically orientated genetic research and patient care since 1949 have resulted in human genetics being both, a basic medical and a basic biological science. Prior to 1949 genetics was not generally viewed in a medical context. Although monogenic human diseases were recognized in 1902, their occurrence and distribution were considered mainly at the population level.
\end{abstract}

\section{Introduction}

With the completion of the Human Genome Project in 2004 [1] human genetics moved into a new era of exploring the whole genome and its relation to the causes of genetic disorders. New approaches based on numerous new technological advances, such as different automated DNA sequencing methods [2], the elucidation of different types of individual genetic variation [3] and others, allow high resolution analysis of the human genome in various genetic etiologies of diseases $[4,5]$ in a great number of individuals in different geographic populations [6-9] or analysis of single cells [10]. Earlier genetic studies in human genetics were aimed at individual genes or groups of linked genes. In contrast, during the first 4-5 decades of increasing

Supplementary information The online version of this article (https:// doi.org/10.1038/s41431-020-00785-7) contains supplementary material, which is available to authorized users.

Eberhard Passarge

eberhard.passarge@uni-due.de

1 Institut für Humangenetik, Universitätsklinikum Essen, Essen, Germany knowledge of general genetics since 1900, aspects relating to humans could rarely be considered [11-17]. The term "human genetics" has only been in wide use since 1949 on. "Man is one of the most unsatisfactory of all organisms for genetics studies." One sentence later: "Obviously no geneticist would study such a refractory object, were it not for the importance that a knowledge of the subject has in other fields." Thus wrote Alfred H Sturtevant in 1954 [18], expressing an opinion widely held among geneticists before the advent of human genetics (Extended Text \#1 in Supp. Mat.).

How did human genetics arise? Here I propose that the origins of human genetics as an independent scientific field can best be traced to the years between 1949 and 1959, when genetic advances could be applied to humans. Several scientific events took place in 1949 that support this idea. In addition, I will briefly review advances relating to human genetics as they apply to medicine and patient care before and after 1949, much of it as a personal witness since 1963.

\section{The year 1949}

Two new important insights in 1949 serve as hallmarks in the development of early human genetics. James V Neel 
described sickle cell anemia as an autosomal recessive trait [19] and four months later in the same volume of Science Linus Pauling identified this disorder as a "molecular" disease [20]. In 1949 JBS Haldane estimated the mutation rate in humans based on an analysis of seven human diseases to be about $4 \times 10^{-5}$ [21]. Also in 1949, in a publication entitled "Disease and Evolution" JBS Haldane viewed infectious diseases as having potential as an "agent for natural selection" in man [22].

Another landmark paper in 1949 described the serendipitous discovery of a cytologically visible structure in the nucleus of neurons of female cats, but not in males [23]. Subsequently named Barr body, later X-chromatin, this eventually led to the principle of $\mathrm{X}$-chromosome inactivation [24]. The examples above constitute a shift in the paradigm in scientific progress as postulated by Kuhn [25]. According to this theory science not only progresses as continuous accumulation of knowledge, but also by periods of a new paradigm by asking completely new questions in a new context [26].

For additional reasons the year 1949 can be considered a watershed time point from which modern human genetics developed. In 1949 the American Journal of Human Genetics was established, a year after the founding of the American Society of Human Genetics (ASHG). Curt Stern (1902-1981), one of the leading geneticists between 1923 and 1970, published the first textbook in this field, Principles of Human Genetics [27].

The first two meetings of the ASHG took place in September 1948 in Washington, DC, and December 1949 in New York City, both under HJ Muller as president. The title of Muller's presidential address presented at the second annual meeting of the ASHG in 1949 was "Our Load of Mutations" [28]. This was mainly concerned with the consequences of mutations in humans at the population level.

In 1940 in Britain, a textbook appeared entitled An Introduction to Medical Genetics by Fraser Roberts [29]. This was the first textbook on medical genetics, and the only one for many years.

The year 1949 is also noteworthy for human genetics in post-war Germany (Extended Text \#2 in Supp. Mat.).

\section{Early advances}

The transition from general genetics to human genetics is characterized by recognizing the medical aspects. Newly discovered chromosome abnormalities, hereditary metabolic defects and molecular technology resulted in defining new human diseases due to different genetic causes. Human genetics includes medical genetics, devoted to all of its medical aspects and clinical genetics, the practice of diagnosis and management of genetic disorders. McKusick in 1993 stated that clinical genetics originated in 1959 when human cytogenetics and biochemical genetics developed into mainstream subjects of research and its medical applications [30]. The term genomics, derived from genome (coined by Winkler in 1920), was introduced in 1987 [31]. It relates not only to all genes, but also to the molecules regulating their functions and nuclear structures.

The European Society of Human Genetics (ESHG) was founded at the Third International Congress of Human Genetics in 1966 in Chicago, with the author of this review and Albert de la Chapelle present. Its first annual meeting was held 1968 in Paris.

\section{Chromosomes}

Human genetics is a theory-driven science, but it also greatly depends on advances in methods of investigation. Probably the most important single contribution to the development of modern human genetics was that of cytogenetics in 1959 [32-36]. At first, individual chromosomes in mitosis could not yet be individually identified distinguished except for a few chromosome pairs (Extended Text \#3 in Supp. Mat.). New cell culture methods and improved mitotic chromosomal preparations for light microscopic analysis directly led to the recognition in 1959/ 60 that several human disorders result from defined aberrations in the number or structure of chromosomes (Trisomies 21, 18, 13; partial chromosomal deletions or duplications). Since each aberration was associated with a distinct phenotype, a relationship between a genotype and a phenotype could be defined. In 1959, individuals without a Y chromosome were shown to be female [37], whereas those with a Y chromosome were male no matter how many $\mathrm{X}$ chromosomes were present [38]. This was the first step towards defining the fundaments of mammalian sex determination. In the 1960s and 1970s it became apparent that fetal death is frequently caused by chromosomal aberrations that are not observed in newborns. Although chromosomes in metaphase were described as early as 1879 , the correct number of human chromosomes was not established until 1956 (Extended Text \#4 in Supp. Mat.).

\section{Cell cultures and biochemical defects}

From the 1960s on, cultured cells became widely used to investigate monogenic human diseases (somatic cell genetics). Cells homozygous for a genetic defect could be distinguished from heterozygous cells. Fused homozygous cells from different patients (cell hybrids) could result in a normal cellular phenotype, proving the disease in question to be genetically heterogeneous. Biochemical assays began to define human hereditary metabolic diseases such as amino acid disorders, lysosomal storage diseases, and others at the level of the phenotype and genotype. Prenatal genetic diagnosis was introduced in the late 1960s. 
Table 1 Examples of new genetic disorders described 1949-2009.

\begin{tabular}{|c|c|c|c|}
\hline Year & Disorder & OMIM & Genes involved \\
\hline \multirow[t]{2}{*}{1952} & $\mathrm{X}$-linked agammglobulinemia type Bruton & 300300 & BTK at Xq22.1, a B-cell regulator \\
\hline & Lowe syndrome (Inositol phosphate metabolism) & 309000 & OCRL (300535) at Xq26.1 \\
\hline \multirow[t]{2}{*}{1954} & Bloom syndrome (DNA helicase disorder) & 210900 & RECQL3 (604610) at $15 q 26.1$ \\
\hline & Russell-Silver syndr. (Heterogenous imprinting disorder) & 180860 & Hypomethylation IC $11 \mathrm{p} 15.5 ; 3$ other chromosomes \\
\hline 1956 & Prader-Willi syndrome (imprinting defects) & 176270 & SNRPN, NDN; others at $15 q 11.2$ \\
\hline 1958 & Ataxia telangiectatasia (ATT; Louis-Bar; see NBS 1981) & 208900 & ATM (601232) at $11 \mathrm{q} 22.3$ \\
\hline 1959 & Alström syndrome (Ciliopathy, centriole function) & 203800 & ALMS1 (606844) at $2 \mathrm{p} 13.1$ \\
\hline 1960 & Trisomy 18 , Trisomy 13 & None & New malformation syndromes \\
\hline $1961 / 62$ & Williams-Beuren syndrome (contiguous gene syndrome) & 194050 & homozygous del $7 q 11.23$ of $1.5-1.8 \mathrm{Mb}$ \\
\hline 1962 & Menkes disease ( $\mathrm{Cu}$ transport metabolism) & 309400 & ATP7A (300011) at Xq21.1 \\
\hline \multirow[t]{3}{*}{1963} & Deletion 5p (Cri-du-chat syndrome) & 123450 & Terminal deletions at 5p15.2-p15.3 \\
\hline & Rubinstein-Taybi syndr (transcriptional coactivator defect) & 180849 & del 16p13.3 (CREBBP 600140); 22q13.2 EP300 (602700) \\
\hline & Miller-Dieker (lissencephaly complex) & 247200 & Deletions at $17 \mathrm{p} 13.3$ and others, involving 11 genes \\
\hline \multirow[t]{6}{*}{1964} & Deletion 4p (Wolf-Hirschhorn syndrome) & 194190 & Terminal deletions at $4 \mathrm{p} 16.3$ \\
\hline & Smith-Lemli-Opitz syndrome (Cholesterol metabolism) & 270400 & DHCR7 (602858) at $11 \mathrm{q} 13.4$ \\
\hline & Lesch-Nyhan syndrome (Purin metabolism) & 300322 & HPRT1 (308000) at Xq26.2-q26.3 \\
\hline & Sotos syndrome (see Weaver syndr. 1974) & 117550 & NSD1 (606681) at 5q35; APC2; NFIX \\
\hline & Pfeiffer syndr.(Fibrobast growth factor receptor defects) & 101600 & FGFR1 at 8 p11.23; FGFR2 at $10 \mathrm{q} 26.13$ \\
\hline & Alagille (2 types; disrupted NOTCH signaling pathway) & 118450 & JAG1 at $20 \mathrm{p} 12.2 ; \mathrm{NOTCH} 2$ at $1 \mathrm{p} 12$ \\
\hline 1965 & Angelman syndrome (Imprinting defects) & 105830 & UBE3A at $15 \mathrm{q} 11.2$ \\
\hline 1966 & Langer-Giedion syndr. (Trichorhinophangeal syndrome) & 190350 & TRPS1 (604386) at 8q23.3 (Zn-finger transcription factor) \\
\hline \multirow[t]{3}{*}{1967} & I-cell disease (Mucolipidosis II; lysosomal storage) & 252500 & GNPTAB $(607840)$ at $12 \mathrm{q} 23.2$ \\
\hline & Thanatophoric dysplasias (FGF receptor defects) & 187600 & FGFR3 (134934) at 4p16.3 \\
\hline & Zellweger syndrome (Peroxisome disorders) & 214100 & Mutations in PEX genes at 13 loci \\
\hline \multirow[t]{3}{*}{1968} & Xeroderma pigmentosum (DNA repair disorders) & 278700 & XPA-XPG (7 autosomal loci, one X-linked XPV) \\
\hline & Noonan syndrome (RAS-MAPK signaling defects) & 163950 & PTPN11 (176876) and 12 other genes \\
\hline & DiGeorge syndrome (see Shprintzen syndr. 1981) & 188400 & TBX1 haploinsufficiency del at 22q11.2 \\
\hline \multirow[t]{5}{*}{1969} & Fragile X-syndrome (Martin-Bell syndr.) & 300624 & FMR1, CGG repeat expansion \\
\hline & Beckwith-Wiedemann syndrome (Imprintig defects) & 130650 & Mutat. or del of one of four imprinted genes at $11 \mathrm{p} 15.5$ \\
\hline & EEC syndrome (one of 6 phenotypes involving TP63) & 129900 & TP63 (603273) regulator gene at 3q28 \\
\hline & LEOPARD syndrome (3 types) & 151100 & PTPN11 (176876), RAF1 (611664), BRAF \\
\hline & Joubert syndrome type 1 (Ciliopathies) & 213300 & 16 autosomal genes, $1 \mathrm{X}$-linked \\
\hline 1970 & Coffin-Siris syndrome (Chromatin dysregulations) & 135900 & ARID1A (614556) and 10 other genes \\
\hline 1972 & Townes-Brocks syndrome ( 3 genetic types) & 107480 & SALL1 transcription factor at 16q12.1; DACT1 (607861) \\
\hline 1974 & Weaver syndr. (see Sotos 1964 (Chromatin disorders) & 277590 & $\mathrm{EZH} 2(601573)$ at $7 \mathrm{q} 36.1$ (Nucleosome histone $\mathrm{H} 3$ function \\
\hline 1975 & Antley-Bixler syndrome (2 types) & 201750 & POR (124015) P450 oxidoreductase in type 1 ; FGFR2 type 2 \\
\hline \multirow[t]{2}{*}{$1977 / 79$} & Wiedemann-Rautenstrauch syndr. (Progeroid disorder) & 264090 & POLR3A (614258) RNA polymerase III \\
\hline & Costello syndrome (RAS-MAPK signaling pathway) & 218040 & HRAS at $11 \mathrm{p} 15.5$ (see Noonan 1968) \\
\hline \multirow[t]{3}{*}{1981} & Nijmegen breakage syndrome (see ATT 1958) & 251260 & $\mathrm{NBN}(602667)$ at $8 \mathrm{q} 21.3$ \\
\hline & Shprintzen syndrome (Velocardiofacial) & 192430 & del 1.5-3.0 Mb at 22q11 (see DiGeorge 1968) \\
\hline & Kabuki make-up syndr. (Chromatin regulatory disorders) & 147920 & Two types: KMT2D at $12 \mathrm{q} 13.12 ; \mathrm{KDM} 6 \mathrm{~A}$ at Xp11.3 \\
\hline \multirow[t]{2}{*}{1986} & Smith-Magenis syndrome (see Potocki-Lupski 2000) & 182290 & del 17p11.2, gene RAI1 (607642) \\
\hline & Cardio-facio-cutaneous syndr. (RAS-MAPK pathway) & 115150 & BRAF $(164757)$ at $7 q 34$ \\
\hline 1993 & Nicolaides-Baraitser syndr. (Chromatin dysregulation) & 601358 & SMARCA2 (600014) at $9 \mathrm{q} 24.3$ \\
\hline 1997 & Muenke syndrome (Fibroblast growth factor receptor) & 602849 & FGFR3 (134934) at $4 \mathrm{p} 16.3$ \\
\hline 2000 & Potocki-Lupski syndrome (see Smith-Magenis 1986) & 610883 & dup 17.p11.2 \\
\hline 2006 & Loeys-Dietz syndrome (Transforming growth factor) & 609192 & TGFBR1 (190181) at 9q22.33 \\
\hline \multirow[t]{3}{*}{2009} & Kleefstra syndr. (phenotypic series with about 50 members) & 610253 & EHMT1 (Eurchromatic histone methyltransferase) \\
\hline & Data based on OMIM [49]. This list is not complete. & & \\
\hline & $\begin{array}{l}\text { The new microdeletion/microduplication syndromes since about } \\
1985 \text { are not included }\end{array}$ & & \\
\hline
\end{tabular}

\section{Molecular advances}

Beginning in 1974 DNA could be analyzed by applying new recombinant DNA methods directly, or indirectly by using linked polymorphic DNA markers. New methods to sequence DNA nucleotides in 1977 and to amplify small amounts of DNA in 1985 (PCR) resulted in precise genetic diagnoses with correct assessment of the genetic risk within 
a given family. Molecular cytogenetics was introduced shortly after 1985. This allowed the analysis of mitotic chromosomes by in situ DNA hybridization. Submicroscopic chromosomal alterations (less than 4 million base pairs of DNA) became visible. New automated massive parallel DNA sequencing methods ("next generation") introduced in 2005 have made it possible to sequence the DNA of large numbers of individuals and tumor cells at relatively low cost [2, 4]. Other new approaches have become possible: genome-wide association studies (GWAS), exome sequencing, whole genome sequencing, and others.

\section{Genetics in medicine}

From about 1960 on genetics included its medical aspects. McKusick in 1992 reviewed the development of human genetics from the First International Congress of Human Genetics in 1956 at Copenhagen to 1991 [39]. He noted that by 1992 human genetics had become "medicalized, subspecialized, professionalized, molecularized, consumerized, commercialized". Systematic genetic diagnostic services and genetic counseling became part of patient care [40]. The American Board of Medical Genetics was established in 1979, the American College of Medical Genetics in 1992.

Details of the early stages of developing human genetics are reviewed by McKusick [40], Polani [41], Harper [42, 43], Harper et al. [44]; McKusick \& Harper and Childs \& Pyeritz [45, 46], and more recently Clausnitzer et al. [4]. Childs in 1999 and 2013 [47, 48] has drawn attention to two views of disease: the classification of diseases differs in medicine and medical human genetics. In medicine it is mainly based on the phenotype, i.e., clinical manifestation, whereas the genetic classification system is based on the genotype, i.e., different types of mutations or other structural rearrangements. Table 1 lists the main genetic features of genetic disorders first described by their phenotypes since 1949. It is remarkable that many of these recognizable phenotypes were not described earlier, such as, e.g., trisomy 18 , whereas the phenotype of trisomy 13 was described in 1657 (Thomas Bartholin, "Monstrum sine oculis"). Most disorders listed in Table 1 can be classified according to their genotypes rather than their phenotypes. Their classification is based on different pathogenic causes, such as impaired functions in genome structure, chromatin regulation, cell receptors, transcription factors, signaling pathways, imprinting, and others (for other examples of genetic classification of diseases see Extended Text \#5 in Supp. Mat.).

Table S1 lists examples of major advances in human genetics between 1949 and 2020. The criteria for selection are based on how each entry has been perceived in the literature and personal observations since 1963. The left column contains advances directly relating to human genetics, and the right column entries indirectly contributing to human genetics.

Nowhere is the enormous progress in the medical aspects of human genetics (medical genetics), in particular for monogenic disorders, more visible than in Mendelian Inheritance in Man. A Catalog of Human Genes and Genetic Disorders (Fig. S1). This was first established in 1966 by Victor A McKusick (1921-2008) at Johns Hopkins University in Baltimore and went through 12 printed editions (1966-1998). Since then it is maintained online as Online Mendelian Inheritance in Man (Ref. [49], online freely available at OMIM: www.ncbi.nlm.nih.gov/omim). CF Fraser and H Harris in 1956 independently established genetic heterogeneity as a basic principle in medical genetics [50-53]. Scriver in 1999 [54] first demonstrated that modifying genes influence the phenotype, severity and course of illness in monogenic disorders [55-57]. An important shift of paradigm in genetics occurred when the concept of genetic counseling was introduced (Extended Text \#6 in Supp. Mat.).

\section{Advances in general genetics applied to humans prior to 1949}

Prior to 1949 none of the many discoveries in genetics could be derived from direct observations in humans. Advances in genetics generally were not seen in a medical context with patient care. Knowledge of human genetic disorders was aimed at the population level rather than individually to patients and their families. Monogenic Mendelian disorders were viewed as being too rare to be relevant for medical applications and patient care. Complex disorders with multifactorial etiologies had not yet revealed their genetic components. Several of the early genetic investigations in humans were directed at the genetics of normal traits such as stature, color of the eye, skin, hair, mental abilities and the like. They came to erroneous conclusions because the underlying genetic properties are not as simple as assumed at the time. Several presidents of the American Society of Human Genetics and others have reflected on the status of human genetics before 1949 (Extended Text \#7 in Supp. Mat.).

A few earlier attempts related genetic knowledge to humans. Neel in 1939 initiated a seminar on human genetics together with Curt Stern (Extended Text \#8 in Supp. Mat.). In 1940 in Britain, a textbook appeared entitled An Introduction to Medical Genetics by Fraser Roberts [29]. This was the first textbook on medical genetics, and the only one for many years (Extended Text \#9 in Supp. Mat.). In Germany in 1923 a 500-page textbook entitled "Human Heredity Science and Racial Hygiene" went through five editions until 1940 (Extended Text \#10 in Supp. Mat.). 
In 1934 A Følling described phenylketonuria (OMIM 261600) as a cause of mental retardation. After GA Jervis recognized the enzyme defect in 1947, and H Bickel in 1953 delineated an approach to dietary therapy, R Guthrie in 1962 set the stage for population-wide screening of newborns for early diagnosis and effective therapy. Today a great number of hereditary metabolic disorders can be identified in newborns prior to clinical manifestation.

In general however, advances in genetics were not considered in relation to medicine. This would have required a shift in paradigm, which did not occur at that time. A gross misconception in applying genetic considerations to humans in the 1920s and 1930s was Eugenics (Extended Text \#11 in Supp. Mat.).

\section{Prescient insights}

Three remarkable exceptions with early genetic insights relating to humans can be cited here: William Bateson, Archibald E Garrod, and Theodor Boveri. They can be considered forerunners of human genetics. William Bateson (1861-1926) at Cambridge in his Principles of Heredity in 1913 [12] described several human pedigrees with autosomal dominant, recessive, and X-linked inheritance (pp. 203-234). Bateson states on page 233: "Similarly when we find that a condition such as retinitis pigmentosa sometimes descends in one way and sometimes in another, we may perhaps expect that a fuller knowledge of facts would show that more than one pathological state may be included under the same name" [12]. Thus, Bateson recognized genetic heterogeneity more than 40 years before $\mathrm{CF}$ Fraser and $\mathrm{H}$ Harris in 1956 independently established it as a basic principle in human genetics (see above). Other examples of early descriptions of Mendelian inheritance of human diseases are heritable biochemical defects, described by Archibald Garrod as "inborn errors of metabolism" [58-60] or brachydactyly type A1 (OMIM 112500) by WC Farabee in a $\mathrm{PhD}$ thesis published in 1905, reviewed by Haws \& McKusick in 1963 [61] and Bateson, 1913, page 210-216 [12].

Archibald E Garrod (1857-1936) at Great Ormand Street Hospital London recognized the genetic individuality of man. In a letter to Bateson on 11 January 1902, Garrod wrote: "I believe that no two individuals are exactly alike chemically any more than structurally (Ref. [60], Bearn, 1993, page 61). In his prescient monograph Inborn Factors of Disease of 1931 Garrod considered predisposition to disease to be important $[47,48,60]$. A remarkable insight pointing to the importance of genetics in human diseases is contained in Thomas H Morgan's Nobel lecture in 1934, The relation of genetics to physiology and medicine: “... considering the present attitude of medicine and the dominating place of the constitutional researches, the role of the inner, hereditary factors to health and disease appears in a still clearer light. For the general understanding of maladies, for prophylactic medicine, and for the treatment of diseases, hereditary research thus gains still greater importance" (cited by Bearn, 1993, ref. [60], page 193).

The third example is Theodor Boveri (1862-1915) at Würzburg. By 1902 he had recognized the individuality of chromosomes [62]. Subsequently Boveri related changes in chromosomes to the causes of cancer [63, 64]. However, more than four decades went by until 1960 when the Philadelphia chromosome was described in chronic myelogenous leukemia [65, 66]. The "One Gene - One Enzyme" hypothesis proposed by George W Beadle in 1941 could have become a corner stone of human biochemical genetics. Beadle referred to Garrod in his Nobel lecture in 1958 (cited by Bearn, 1993, ref. [60], page 150).

\section{Diversity of modern human genetics}

Modern human genetics has evolved in different directions mainly based on different methods of investigation, although in research it is by no means limited to Homo sapiens. Today it comprises genomics with several subsections (e.g., proteomics, epigenomics and others), molecular genetics, tumor genetics and -genomics, pharmacogenetics and -genomics, immunogenetics, epigenetics, cytogenetics, somatic cell genetics, biochemical genetics, population genetics, evolutionary bases of causes of disorders, bioinformatics and others. This is extensively reviewed in two current multivolume online textbooks [67, 68]. No vertebrate genetics or genomics is better understood than that of man. Yet, human genetics is not an established curriculum of study within the faculties of either medicine or biology. Rather, to become a human geneticist one must study medicine or a basic science and complete approximately five years of formal postgraduate training. Thus, human geneticists represent either a medical or a nonmedical basic science. This dual structure of being both a medical and a biological discipline makes human genetics unique among the medical subspecialities, as outlined in detail by Childs [47, 48].

\section{Conclusion}

In summary, modern human genetics began when new advances in genetics were systematically applied in medicine from 1949 on. A close relationship between genetics and medicine evolved into human genetics. This contributes greatly to an understanding of the causes of human diseases. In addition, genetic counseling based on empathy and free decision-making of individuals has become part of patient care. Human genetics had become "medicalized" [40]. 
Acknowledgements Frank Kaiser, Bernhard Horsthemke, Christel Depienne, Jasmin Beygo and Deniz Kanber provided valuable comments. Mary F Passarge made useful suggestions about the style of the text. I thank three anonymous reviewers for constructive criticisms and helpful suggestions.

Funding Open Access funding enabled and organized by Projekt DEAL.

\section{Compliance with ethical standards}

Conflict of interest The author declares no conflict of interest.

Publisher's note Springer Nature remains neutral with regard to jurisdictional claims in published maps and institutional affiliations.

Open Access This article is licensed under a Creative Commons Attribution 4.0 International License, which permits use, sharing, adaptation, distribution and reproduction in any medium or format, as long as you give appropriate credit to the original author(s) and the source, provide a link to the Creative Commons license, and indicate if changes were made. The images or other third party material in this article are included in the article's Creative Commons license, unless indicated otherwise in a credit line to the material. If material is not included in the article's Creative Commons license and your intended use is not permitted by statutory regulation or exceeds the permitted use, you will need to obtain permission directly from the copyright holder. To view a copy of this license, visit http://creativecommons. org/licenses/by/4.0/.

\section{References}

1. International Human Genome Sequencing Consortium. Finishing the euchromatic sequence of the human Genome. Nature 2004;431:931-45.

2. Shendure J, Balasubramanian S, Church G, Gilbert W, Rogers J, Schloss JA, et al. DNA sequencing at 40: past, present and future. Nature. 2017;550:345-53.

3. Lek M, Karczewski KJ, Minikel EV, Samocha KE, Banks E, Fennell T, et al. Analysis of protein-coding genetic variation in 60,706 humans. Nature. 2016;536:285-91.

4. Clausnitzer M, Cho JH, Collins R, Cox NJ, Dermitzakis ET, Hurles ME, et al. A brief history of human disease genetics. Nature. 2020;577:179-89.

5. Astle WJ, Freson K, Megy K, Raymond FL, Quwehand WH, Stirrups KE, et al. Whole-genome sequencing of patients with rare diseases in a national health system. Nature. 2020;583:96-102.

6. Ruderfer DM, Hamamsy T, Lek M, Karczewski KJ, Kavanagh D, Samocha KE, et al. Patterns of genic intolerance of rare copy number variation in 59,989 human exomes. Nat Genet. 2016;48:1107-11.

7. Nielsen R, Akey JM, Jakobsson M, Pritchard JK, Tischkoff S, Willerslev E. Tracing the peopling of the world through genomics. Nature. 2017;541:302-10.

8. Bergström A, McCarthy SA, Hui R, Almarri MA, Ayub Q, Danecek $\mathrm{P}$, et al. Insights into human genetic variation and population history from 929 diverse genomes. Science. 2020;367: eaay5012.

9. Abel HJ, Larson DE, Chiang C, Das I, Lanchi KL, Layer RM, et al. Mapping and characterization of structural variation in 17,795 human genomes. Nature. 2020;583:83-9.

10. Tan L. Three-dimensional genome structure of a single cell. Science. 2019;366:964-5
11. Johannsen W. Elemente der exakten Erblichkeitslehre. G Fischer, Jena, 1926 (first edition 1909).

12. Bateson W. Mendel's principles of heredity. Cambridge University Press;Cambridge:1913 (first edition 1909).

13. Morgan TH, Sturtevant AH, Muller HJ, Bridges CB. The mechanism of mendelian heredity. New York: Henry Holt \& Co; 1915.

14. Morgan TH, The theory of the gene. New Haven: Yale University Press; 1926.

15. Sturtevant $\mathrm{AH}$, Beadle GW, An introduction to genetics. New York: Dover Publications; 1939. (2nd ed. 1962).

16. Dunn LC, A short history of genetics. In: The Development of the Main Lines of Thought: 1864-939. New York: McGraw-Hill Book Co; 1965.

17. Sturtevant AH, A history of genetics. New York: Harper \& Row; 1965. (reprinted by Cold Spring Harbor Laboratory Press, 2001).

18. Sturtevant AH. Social implications of the genetics of man. Science. 1954;120:405-7.

19. Neel JV. The inheritance of sickle cell anemia. Science. 1949;110:64-6.

20. Pauling L, Itano HA, Singer SJ, Wells IC. Sickle cell anemia a molecular disease. Science. 1949;110:543-8.

21. Haldane JBS. The rate of mutation of human genes. Hereditas. 1949;35:267-73.

22. Lederberg J, Haldane JBS. (1949) on infectious disease and evolution. Genetics. 1999;153:1-3.

23. Barr ML, Bertram EG. A morphological distinction between neurons of the male and female, and the behaviour of the nucleolar satellite during accelerated nucleoprotein synthesis. Nature. 1949;163:676-7.

24. Lyon MF. Gene action in the X-chromosome of the mouse (Mus musculus). Nature. 1961;190:372-3.

25. Kuhn TS. The Structure of Scientific Revolutions. Chicago: University of Chicago Press; 1962 (2nd ed 1970, 3rd 1996, 4th ed 2012).

26. Kaiser D. In retrospect: the structure of scientific revolutions. Nature. 2012;484:164-5.

27. Stern C. Principles of human genetics. San Francisco: WH Freeman; 1949. (2nd edition 1960, 3rd and last 1973).

28. Muller HJ. Our load of mutation. Am J Hum Genet. 1950;2:111-76.

29. Fraser Roberts JA, An introduction to medical genetics. Oxford: Oxford University Press; 1940. (With several subsequent editions with co-authors, 7th in 1978).

30. McKusick VA. Medical Genetics. A 40-year perspective on the evolution of a medical speciality from a basic science. JAMA. 1993;270:2351-6.

31. McKusick VA, Ruddle FH. A new discipline, a new name, a new journal. Genomics. 1987;1:1-2.

32. Polani PE. Human and clinical cytogenetics: origins, evolution and impact. Eur J Hum Genet. 1997;5:117-28.

33. Hsu TC. Human and mammalian cytogenetics. An historical perspective. Heidelberg-New York: Springer; 1979.

34. Miller OJ, Therman E. Human Chromosomes. 4th ed. New YorkHeidelberg: Springer; 2001.

35. Harper P. The Beginnings of Human Cytogenetics. Oxford: Skion Publishing; 2006.

36. Ferguson-Smith MA. History and evolution of cytogenetics. Mol Cytogenet. 2015;8:19.

37. Ford CE, Jones KW, Polani PE, De Almeida JC, Briggs JH. A sex-chromosome anomaly in a case of gonadal dysgenesis (Turner's syndrome). Lancet. 1959;1:711-113.

38. Jacobs PA, Strong JA. A case of human intersexuality having a possible XXY sex-determining mechanism. Nature. $1959 ; 183: 302-3$ 
39. McKusick VA. Presidential address. Eighth International Congress of Human Genetics: The last 35 years, the present and the future. Am J Hum Genet. 1992;50:663-70.

40. McKusick VA. The growth and development of human genetics as a clinical discipline. Am J Hum Genet. 1975;27:261-73.

41. Polani PE. Medical and clinical genetics: their roots and challenge. Acta Genet Med Gemellol. 1996;45:127-36.

42. Harper PS, editor. Landmarks in Medical Genetics. Classic Papers with Commentaries. Oxford Monographs on Medical Genetics. Oxford: Oxford University Press; 2004.

43. Harper PS. A short history of medical genetics. Oxford: Oxford University Press; 2008.

44. Harper PS, Reynolds LA, Tansey T, eds. 2010. Clinical Genetics in Britain: origins and development. Wellcome Witnesses to Twentieth Century Medicine, vol. 39. London: Wellcome Trust Centre for the History of Medicine at UCL.

45. Childs B, Pyeritz RE. Medicine in a genetic context. Chapter 2. In: Rimoin DL, Pyeritz R, Korf B, eds. Emery and Rimoin's principles and practice of medical genetics. 6th ed. New York: Elsevier; 2013.

46. McKusick VA, Harper PS: History of Medical Genetics. Chapter 1, p. 1-38. In: Emery and Rimoins principles and practice of medical genetics. 6th ed. DL Rimoin, RE Pyeritz, BR Korf, editors. Elsevier, New York, 2013 (E-book only).

47. Childs B. Genetic medicine. A Logic of Disease. Baltimore, London: Johns Hopkins University Press; 1999.

48. Childs B. A Logic of Disease. Chapter 2. In: The online metabolic and molecular bases of inherited disease. New York: Elsevier; 2013.

49. OMIM. Online Mendelian Inheritance of Man (www.ncbi.nlm. nih.gov/omim).

50. Fraser FC. Heredity counseling. The darker Side- Eugen Quart. 1956;3:45-51.

51. Harris H. An Introduction to Human Biochemical Genetics. 3rd edition. North-Holland Biomed. Press, Amsterdam, 1980 (pp. 417-23: Heterogeneity of inherited disease. First edition, Cambridge University Press, Cambridge, 1959; (2nd ed. 1970).

52. Childs B, Der Kaloustian VM. Genetic heterogeneity. New Eng. N Eng J Med. 1968;279:1267-74.

53. McKusick VA. Phenotypic diversity of human diseases resulting from allelic series. Am J Hum Genet. 1973;25:446-56.
54. Scriver CR. Monogenic traits are not simple. Trends Genet. 1999;15:3-8

55. Drumm ML, Konstan MW, Schluchter MD, Allison Handler RN, Pace R, Zou F, et al. Genetic modifiers of lung disease in cystic fibrosis. N. Eng J Med. 2005;353:1443-53.

56. Gu Y, Harley ITW, Henderson LB, Aronow BJ, Vieto I, Huber LA, et al. Identification of IFRDI as a modifier gene for cystic fibrosis lung disease. Nature. 2009;458:1039-42.

57. Bello L, Flanigan KM, Weiss RB, McDonald CM, Hoffman EP. Association study of exon variants in the NF-KB and TGF $\beta$ pathways identifies $C D 40$ as a modifier of Duchenne muscular dystrophy. Am J Hum Genet. 2016;99:1163-71.

58. Garrod AE. The incidence of alkaptonuria: a study in chemical individuality. Lancet. 1902: ii:1616-20.

59. Garrod AE. The inborn factors in disease. Oxford: Clarendon Press; 1931.

60. Bearn AG. Archibald garrod and the individuality of man. Oxford: Clarendon Press; 1993.

61. Haws DC, McKusick VA. Farabee's brachydactylous kindred revisited. Bull Johns Hopkins Hosp. 1963;113:20-30.

62. Boveri T. Über mehrpolige Mitosen als Mittel zur Analyse des Zellkerns. Verh phys-med Ges Würzburg. 1902;35:67-90.

63. Boveri T. Zur Frage der Entstehung maligner Tumoren. Gustav Fischer, Jena, 1914. Cold Spring Harbor Laboratory Press; 2008. (English edition: H. Harris, Concerning the Origins of Malignant Tumors).

64. Holland AJ, Cleveland DW. Boveri revisited: Chromosomal instability, aneuploidy and tumorigenesis. Nat Rev Cell Biol. 2009; $10: 478-87$.

65. Nowell P, Hungerford D. A minute chromosome in chronic granulocytic leukemia. Science. 1960;132:1488-501.

66. Rowley JD. A new consistent chromosomal abnormality in chronic myelogenous leukemia identified by quinacrine fluorescence and Giemsa staining. Nature. 1973;243:290-1.

67. Pyeritz RE, Korf B, Grody WW, editors. Emery and Rimoin's Principles and Practice of Medical Genetics. 7th ed. New York: Elsevier; 2019.

68. Valle DL, Antonarakis S, Ballabio A, Beaudet AL, Mitchell GA, editors. The online metabolic and molecular bases of inherited disease (OMMBID). McGraw-Hill Education; 2019 (E-book only). 